DOI:10.30842/ielcp230690152272

E. Parina

\title{
THE GOOD, THE BAD AND THE TRANSLATOR: THE CONCEPT OF PREDESTINATION IN A MIDDLE WELSH TRANSLATION OF THE ELUCIDARIUM
}

В статье рассматриваются лексические решения, принимаемые средневаллийским переводчиком текста Элюцидария, при переводе латинских слов, относящихся к понятию предопределения. Решения эти зачастую далеки от терминологической точности. Основной причиной этого, возможно, является изменение круга читателей валлийского текста по сравнению с латинским. Валлийский текст ориентирован на мирян, желающих иметь в своем распоряжении изложение основ вероучения на своем родном языке, поэтому переводчик в отдельных местах упрощает латинский текст.

Ключевые слова: Средневаллийский язык, средневаллийская литература, средневековые переводы, религиозные тексты, Elucidarium, предопределение.

Predestination or election is a concept that has been characterized as «one of the most controversial in the history of the Christian thought» (Fergusson 2000: 562) ${ }^{1}$. The compatibility of foreknowledge and human freedom, divine providence and love has been discussed by most prominent theologians for centuries. In the Western church Augustine's doctrine was highly influential, but the concept continued to be developed throughout the Middle Ages and later, important discussions taking place in the Carolingian time (when the idea of the double predestination was formed ${ }^{2}$, see Hödl, Laarmann 1999: [2]) and in the 11th-early 12th century, when Anselm of Canterbury (c. 1033-1109) ${ }^{3}$, the father of Scholasticism,

\footnotetext{
${ }^{1}$ This paper is part of the project 'Translations as language contact phenomena: studies in lexical, grammatical and stylistic interference in Middle Welsh religious texts', led by Prof. Erich Poppe at the PhilippsUniversität Marburg, supported by the Fritz Thyssen Foundation.

2 'By Double Predestination, we maintain two acts of predestination: on the one hand, God predestines some of us to receive grace and go to heaven; on the other, he predestines the rest not to receive his grace and go to hell' (Bell 1996: 325). The ones going to heaven are called predestinati 'predestined' (closely related to this notion is also electi 'selected'), the ones going to hell are called damnati 'damned' (and also reprobati 'reprobated').

${ }^{3}$ Cross \& Livingstone 1997 s.v. Anselm, St., p. 73-74.
} 
wrote works such as De Concordia Praescientiae et Praedestinationis et Gratiae Dei cum Libero Arbitrio ( On the Harmony of Foreknowledge and Predestination and the Grace of God with Free Choice», 1107 or 1108).

This leading theologian of his time must have had a strong influence on Honorius Augustodunensis (fl. in early 12th c.) ${ }^{4}$. Anselm was once supposed to have been Honorius' teacher, which is not taken for granted anymore, but whatever the precise relationship, the importance of his works for those of Honorius has long been recognised (see Hannam 2013: 2-40 with references to earlier literature), though it is unclear whether he knew the later texts of Anselm. The works of Honorius were formerly described as 'a curious compound of crude theological statement and sophisticated construction' (Flint 1975: 178), nowadays some scholars reject these 'very general surveys that oversimplify his thought and present Honorius himself as a 'simplistic' thinker' (Hannam 2013: Synopsis) and insist on the complexity of Honorius' understanding of predestination and free will. In his analysis of the Elucidarium Aron Gurevich sides with the first group of scholars and, comparing it to a similar dialogue of Alselm of Canterbury, Cur Deus homo ('Why [did] God [become] man?', 1098) shows that Honorius employs in his work fewer of the subtleties of cutting-edge arguments that were being developed in scholastic thought in his time (Gurevich 1988: 153-175). While it is completely out of the scope of this study to discuss the theology of Honorius, it might be instructive to see what happens to the complex concepts of predestination in a Welsh translation of his Elucidarium.

The Elucidarium is a long dialogue between a student (D. for discipulus) and a master (M. for magister), who discuss various kinds of questions related to the faith. The text has been extremely popular in the Middle Ages, as both the number of Latin manuscripts (only in France 60 of them preserved, cf. Lefèvre 1954: 19) and translations into vernaculars, such as Middle English, Middle French, Old Norse, Spanish and Middle Welsh indicate (see Klunder 2005: 8-14). The Middle Welsh translation Ystoria Lucidar, profoundly studied by Sarah Rowles (2008), is found in six manuscripts, dated 1300-1425, among them Oxford, Jesus College MS. 119, also known from its colophone as Llyfr Ancr Llanddewi

\footnotetext{
${ }^{4}$ Cross, Livingstone 1997 s.v. Honorius 'of Autun' (Augustodunensis), 788.
} 
Brefi, dated 1346, hereinafter L1A. At least for this manuscript we know its readership, for the scribe noted that he wrote the manuscript for Gruffudd ap Llywelyn ap Phylip ap Trahaearn of Cantref Mawr, a member of a noble family with long traditions of supporting both native poetry and the production of manuscripts containing translations of texts from Latin or French (see Foster 1950: 217-221).

Honorius gives the following definition of predestination in his text:

D. Quid est praedestinatio Dei?

M. Ea ordinatio qua ante creatum saeculum quosdam ad suum regnum praeordinavit, de quibus nullus perire possit et omnes salvari necesse sit, et quosdam ad poenam, quos peccatores praescivit, de quibus nullus salvus erit. (Elucidarium II.28; p. 414)

Student: What is is God's predestination?

Master: It is an ordinance, that prearranged before the creation of the world to his kingdom those of whom none can perish and all should be saved, and to the pains those whom He foreknew to be sinners, of whom none will be saved.

The Welsh text reads:

Beth yw. rac anuonedigaeth duw

y llunyeith a wnnaeth duw e hun. gwneuthur y byt y drossi rei o'e teyrnnas ef. Ac ny dichawn nep onadunt mynet yg kyfuyrgoll. Ac yssyd reit ev gwnneuthur oll yn yach. (L1A 32r) ${ }^{6}$

What is the predestination of God? An ordinance that God Himself made creating the world, to turn some to His Kingdom; and none of them can perish, and all must be saved.

The Welsh translator most likely creates ad-hoc a term rhaganfonedigaeth by copying the structure of the Latin term (see Rowles 2008: 155) with its prefix prae- corresponding to rhagdenoting temporal precedence and with the suffix -igaeth to form an abstract noun, which he uses often for this purpose (Rowles 2008: ibid.). The most authoritative Welsh dictionary, Geiriadur Prifysgol

\footnotetext{
${ }^{5}$ Since the Welsh text follows the Latin relatively closely, I will translate the Latin only in this case, in all other instances the translation of the Welsh text by Williams (1892) will be used (with some modifications) which should help in understanding the Latin text, the relevant differences will be commented on.

${ }^{6}$ The Welsh texts are quoted after Luft et al. 2013. I have slightly adapted punctuation and orthography (changing $<6>$ to $<\mathrm{W}>$ ).
} 
Cymru (GPC) suggests that the base for this hapax is anfonedig 'sent, dispatched', from the verb anfon 'to send; to go with (person), accompany', but it does not correspond to the Latin destin- 'to fix, determine' in a compelling way.

The Welsh text differs from the Latin one in a number of aspects. First in every manuscript witness of the Welsh translation the idea of precedence of God's predestination (ante creatum saeculum) is absent, which leaves out an important component. Secondly and most interestingly the entire passage on the ones God knew to become sinners is not present, so that the concept of the double predestination (of those to be saved and those to be damned) does not appear in the Welsh passage, changing the theological value of this statement. From a methodological point of view it is extremely important that there are four Latin manuscripts that also leave the damned ones out (Lefèvre 1954: 415, n. 1). We have therefore no means of deciding whether this omission is due to the wording of the Latin source used or whether this idea, important from the point of view of contemporary theology, was considered insignificant by the Welsh translator.

Even if we can not decide on the cause of the mismatch in this very case, if we look at the Ystoria Lucidar in general we will see that this lack of precise correspondance in the discussion of predestination is found elsewhere in the text as well.

The translator considerably shortens another passage where praedestinatio is used in Latin text:

(2) D. Cum Deus sine initio fuerit, numquid credendum est quod ante creatum mundum quasi solitariam vitam duxerit?

M. Scriptum est: "Quod factum est, in ipso vita erat (Joan., I, 3-4)". In quo patet omnem creaturam semper fuisse visibilem in Dei praedestinatione, quae postea visibilis ipsi creaturae apparuit in creatione, ut artifex qui vult domum construere prius tractat quomodo quaeque velit disponere et machina quae post surgit in aedificio prius stabat in ingenio. Unde dicitur Deus non esse antiquior suae creaturae tempore, sed dignitate. (Elucidarium I.15; p. 363)

The Welsh text as found in the L1A reads:

A oed neb onnyt duw e hun.

Ysgriuennedic yw a wnaethpwyt yndaw. bywyt oed. kanys ef a welei pob creadur o'r a wnaethpwyt gwedy hynny ger y vronn ef $\boldsymbol{y n}$ gynndrychawl. megys y gwyl saer da yn y vedwl pa wed y llunyeitho $y$ weith. a'e adeil. herwyd $y$ ethrylith. Ac yna y dywedir nat hyyn 
duw no'r kreaduryeit herwyd amser. namyn herwyd teilygdawt. (LlA 6r)

D. Was there anyone beside God Himself?

M. It is written: What was made in Him was Life, for He saw every creature that was made afterwards before him presently, as a good artisan sees in his mind in which form he would create his work and leave it according to his skill. And therefore it is said that God is not older than creations in time, but in dignity.

Here praedestinatione is translated as yn gynndrychawl using the adjective cynd(d)rych(i)ol [cyn- 'before' +drych 'mirrow; aspect, vision, sight'+-(i)ol ] 'present (in time or place), that is at hand, in one's sight or presence' (GPC online, s.v. cynddrychiol). In the absence of variant readings in the critical edition by Lefèvre we can tentatively suggest that here the mismatch with the Latin text is due to the work of the translator, whose rendering of this passage is rather free.

Peth(eu) cyndrychol 'present thing(s)' is the phrase we find in Ystoria Lucidar for praesentia, as in another example of a rather loose translation:

D. Quid est providentia Dei?

M. Ea cognitio qua omnia futura praescivit, immo inspexit ut praesentia. (Elucidarium II.22; p. 413)

Beth yw racweledigaeth duw.

Adnabodedigaeth y wybot y pethev rac llaw. Ac o'e hetturyt megys y pethev kynndrychawl. (LIA 31r)

D. What is God's Providence?

M. Recognition to know the things in the future; and to restore them as things present.

In another passage the verb praedestinavit is rendered with a form of the verb rhagweld 'to foresee':

(4) Ad quod palatium praedestinavit quemdam certum numerum electorum militum (Elucidarium I.23; p. 365)

Ac yr llys honno y racwelas ef anuon rif hysbys o etholedigyon. (LlA 7v)

To this palace he fore-saw that He would send a certain number of elect.

However, as seen from example 3 , in the theologically informed system of Honorius the notions of providence (providentia), and 
predestination (praedestinatio) are not the same and it is most likely that the responsibility for a terminological imprecision lies with the Welsh translator.

The past perfect participle of the corresponding verb, praedestinatus, is translated by the Welsh etholedig 'elected':

(5) Et in illa natura qua Deus erat vicit diabolum ut et ipse vicit hominem, et omnibus praedestinatis caelum aperuit et angelis coaequavit, quod solus Deus potuit. (Elucidarium I.118; p. 382) Ac yna goruot ar gythreul herwyd y vot y duw. Ac agori pyrth nef yr etholydigyonn. a e gwneuthur ynn gyffelyp yr egylyonn. (LlA 16v$17 \mathrm{r}$ )

and then He triumphed over the Devil, because He was God, and opened the gates of Heaven to the elect, and made them like the angels

(6) Salvantur praedestinati, si non laborant? (Elucidarium II.31; p. 415)

A vydant jach yr etholedigyonn onny lauuryant. (L1A 32v) Are the elect saved if they do not labour?

Most often (46 times), however, this lexeme translates another Latin past perfect participle, electus:

(7) Cur non sunt omnes electi pariter creati ut angeli? (Elucidarium I.72; p. 374)

Paham na chreawd duw yr holl etholedigyonn ygyt megys y krewyt yr engylyon oll. (L1A 12r)

Why did God not create all the elect together, just as all the angels were created?

Once praedestinatos is substituted in the Welsh text by etifedd, a highly frequent word denoting 'heir' (see GPC online, s.v. etifedd), changing the perspective from the complex theological idea of predestination to the context of lineage and inheritance that is central in Medieval Welsh tradition:

(8) [on the destiny of the fallen Adam]

D. Qualiter debuit ablatum honorem reddere?

M. Diabolum ita vincere, ut ipse victus est ab eo, et seipsum omnesque praedestinatos ad vitam tales restituere quales futuri erant si permansissent. (Elucidarium I.106; p. 380)

Pa wed y talawd ef yr anryded a duc. 
Gorchyvygv kythreul. megys y gorchyuygawd y kythreul yntev. a'e dwyn ac ef a'e etiued yr unched yn vn funut a phei trigessynt yn $y$ hanssawd. (LlA 15v)

D. How did he repay the honour that he took away?

M. By overcoming the Devil, as the Devil had triumphed over him, and by bringing himself and his children to the life, just as if they had remained in their position.

This lack of theological precision at least in the case of the concept of predestination,shown in the previous examples, is most clearly manifested in a passage where praedestinati and reprobati are translated simply as 'the good ones' and 'the bad ones':

(9) D. Si nullus potest salvari nisi praedestinati, ad quid alii creati sunt vel in quo sunt rei qui pereunt?

M. Quidquid praedestinati faciant, perire nequeunt, quia omnia cooperantur illis in bonum, etiam ipsa peccata. Nam post gravia facinora humiliores erunt et de sua salvatione uberiores laudes Deo referunt. Reprobi autem propter electos sunt creati, ut per eos in virtutibus exerceantur et a vitiis corrigantur et eorum collatione gloriosiores appareant et, cum eos in tormentis viderint, de sua evasione amplius gaudeant. Qui etiam propter se ipsos juste pereunt, cum malum sua sponte eligunt, diligunt et vellent sine fine vivere, ut possent sine fine peccare. (Elucidarium II.29; p. 415)

Onny dichawn nep onnyt $\boldsymbol{y}$ rei da vot yn yach. paham y krewyt $y$ lleill. nev paham y kyfuyrgollir y rei camgylus.

Beth bynnac a wnel y rei da ny allant wy vynet yg kyfyrgoll. kannys pob peth a lauuryant yn da hyt ynn oet ev pechawt. kannys gwedy $y$ pechodev gorthrymaf y bydant vfudach gann diolwch y duw $y$ hyechyt ynn frwythlonnach a wnnant. A rei drwc a grewyt o achos yr etholedigyonn. Ac y wnneuthur da onadunt o achos y rei drwc. Ac o'e hemendenav o'e gwydyev. megys y boent gogonedus o welet $y$ lleill. A phan welhont y lleill yn y poennev mwy vyd ev llewenyd vyntev o'e diang. A chyfuyawn yw y rei drwc o'e hachos e hunein mynet yg kyfuyrgoll. kanys o'e bod e hun y dewisassant y drwc. Ac y karant. Ac wynt a vynnynt y byw yn dragywyd. (L1A 32r-v)

D. If none but the good be saved, why were the evil created, or why do the iniquitous perish?

M. Whatever the good do, they cannot perish, for all they do works for good, even their sin; for after their most grievous sins they will be more obedient, thanking God for their salvation; then they will act more fruitfully than before. And the evil were created because of the elect, and for them to do good for the sake of the evil, and to reform them from their vices, so that they may be more glorious by 
seeing the evil; and when they see these in the greatest torments, then greater will their joy be at their escape. And it is just for the wicked to perish owing to themselves, for of their own free will they chose and loved the evil. And they would fain live for ever.

The equivalent $y$ rei $d r w c$ to reprobus is found in Lucidar several times. This usage of seemingly basic terms (bad vs. good) could be either a considerable simplification for the new audience, or else refer to another layer of theological thinking, where bonus and malus are used almost as terms. Starting with Augustine's Enchiridion (Ch. 110) four categories of souls that would be judged differently after death were distinguished, i.e. mali valde, mali non valde, boni valde and boni non valde (the very bad, the not very bad, the very good and the not very good) - and this idea was widely known in early medieval England and Ireland (for a detailed discussion see Ivanov 2010).

All these examples can by no means define the degree of theological or linguistical knowledge of the Welsh translator. Even if he could have misunderstood some of the complicated passages of the Elucidarium, he certainly had enough Latin knowledge to translate the whole treatise creating a new version in Welsh which enjoyed further popularity, so that his mission was successful. It should be remembered that this translation follows a pattern of intellectual and textual transmission similar to that discussed by the author regarding a medical text (see Parina 2015 and Parina fc.). We see a learned textual tradition as a foundation (Dietae universales at particulares translated from Arabic by Constantine the African / theological works of Anselm of Canterbury and his predescessors), a Latin adaptation for a broader readership (De flores dietarum by John of Saint Paul (Johannes de Sancto Paulo) / Elucidarium by Honorius) and finally a Welsh translation which brings this adapted text to a new audience with less knowledge of Latin and, correspondingly, of the latest achievements of European academic thinking. We may therefore tentatively attribute these 'inaccuracies' to the intention of the Welsh translator to present the text to a lay public who would probably not delight in cutting-edge theological subtleties, but wanted a more general instruction in the Christian faith which would also be read by their contemporaries in other vernaculars. 


\section{References}

Bell, D. 1996: Many mansions. An Introduction to the Development and Diversity of Medieval Theology West and East. Spencer, MA: Cistercian Publications (Cistercian studies series, 146). Online verfügbar unter http://www.loc.gov/catdir/enhancements/fy1401/ 96213134-b.html.

Cross, F., Livingstone, E. (eds.) 1997: The Oxford Dictionary of Christian Church. 3rd ed. Oxford: Oxford University Press.

Fergusson, D. A. S. 2000: Predestination. In: Adrian Hastings, Alistair Mason und Alistair Pyper (Hg.): The Oxford Companion to Christian Thought. Oxford: Oxford University Press, 562-564.

Flint, V. I. J 1975: The Elucidarius of Honorius Augustodunensis and Reform in Late Eleventh Century England. In: Revue Bénédictine $85,178-189$.

Foster, I. Ll. 1950: The book of the Anchorite. London: Geoffrey Cumberlege for the British Academy (Sir John Rhŷs memorial lectures, 1949).

GPC Online, 2014: University of Wales Centre for Advanced Welsh \& Celtic Studies, http://www.geiriadur.ac.uk

Gurevich, A. 1988: Medieval popular culture. Problems of belief and perception. Cambridge: Cambridge University Press.

Hannam, W. 2013: The Ineuitabile of Honorius Augustodunensis: A Study in the Textures of early Twelfth-Century Augustinianisms. PhD. Boston College, Boston.

Hödl, L.; Laarmann, M. [1977]-1999: Prädestination/Reprobation, I. Westen. Lexikon des Mittelalters. Stuttgart: Metzler, S. vol. 7, cols $142-145$.

Ivanov, S. V. 2010: [On the division of souls in medieval Irish eschatology]. Indoevropeiskoe yazykoznanie $i$ klassicheskaya filologiya [Indo-European linguistics and classical philology] 14 (1), 366-385.

Иванов, С. В. О разделении душ в средневековой ирландской традиции. Индоевропейское языкознание и классическая филология 14 (I), 366-385.

Klunder, A. 2005: Lucidarius. De Middelnederlandse Lucidarius-teksten en hun relatie tot de Europese traditie. $\mathrm{PhD}$ thesis. Universiteit Leiden, Leiden. https://openaccess.leidenuniv.nl/bitstream/handle/ 1887/13408/Klunder+Lucidarius.pdf?sequence $=4$.

Lefèvre, Y. 1954: L' Elucidarium et les lucidaires. Contribution, par l'histoire d'un texte, à l'histoire des croyances religieuses en France au moyen âge. Paris: De Boccard.

Luft, D.; Thomas, P. W.; Smith, D. M. 2013: Rhyddiaith Gymraeg 13001425. Cardiff University.

http://www.rhyddiaithganoloesol. caerdydd.ac.uk

Parina, E. 2015: A Middle Welsh translation of Flores dietarum. Indoevropeiskoe yazykoznanie i klassicheskaya filologiya [IndoEuropean linguistics and classical philology] 19, 623-629 (= Индоевропейское языкознание и классическая филология 19).

Parina, E. (fc.): Medical Texts in Welsh Translation: Y Pedwar Gwlybwr and Rhinweddau Bwydydd. In: Flood, V., Byrne, A. (eds.): Crossing 
Borders in the Insular Middle Ages. Turnhout: Brepols (Medieval Texts and Cultures of Northern Europe).

Rowles, S. 2008: Yr Elucidarium: Iaith, Strwythur, Cynnwys ac Arwyddocâd y Cyfieithiadau Cymraeg. PhD thesis. Prifysgol Cymru, Aberystwyth.

http://cadair.aber.ac.uk/dspace/handle/ 2160/1877.

Williams, R., Jones, G. H. 1892: Selections from the Hengwrt Mss. preserved in the Peniarth Library. Vol. II. London: Bernard Quaritsch.

\section{E. A. Parina. The good, the bad and the translator: the concept of predestination in a Middle Welsh translation of the Elucidarium}

This paper examines the way several Latin lexemes related to the highly complex concept of predestination are being translated in a Middle Welsh version of the Elucidarium by Honorius Augustodunensis. The Welsh translator of the text as we find it in the manuscript Oxford, Jesus College MS. 119, also known from its colophone as Llyfr Ancr Llanddewi Brefi, dated 1346, is far from being precise in dealing with the Latin theological terminology, translating, for example, praedestinati 'predestined' as y rei da 'the good ones' and reprobati 'reprobated' as y rei $d r w c$ 'the bad ones'. This by no means defines his own linguistic or theological competence. It is much more likely that these 'inaccuracies' are to be attributed to the intention of the Welsh translator to present the text to a lay public who would probably not delight in cutting-edge theological subtleties, but wanted a more general instruction in the Christian faith which would also be eagerly read by their contemporaries in other vernaculars.

Keywords: Middle Welsh, Elucidarium, predestination, medieval translations. 